\title{
Comparative investigations on the activity of leucine aminopeptidase, glutamic oxalacetic transaminase, and alkaline phosphatase in serum
}

\author{
B. G. MUNCK AND K. KJERULF ${ }^{1}$ \\ From the Departments of Internal Medicine and of Clinical Biochemistry, \\ Blegdams Hospital, Copenhagen, Denmark
}

SYNOPSIS These studies on leucine aminopeptidase demonstrate that it has the same significance as alkaline phosphatase in relation to jaundice.

During recent years the leucine aminopeptidase activity in serum has been the object of increasing interest (Fleisher and Butt, 1953; Green, KwanChung Tsou, Bressler, and Seligman, 1955; Fleisher, Butt, and Huizenga, 1957; Goldbarg and Rutenburg, 1958; Rutenburg, Goldbarg, and Pineda, 1958; Braun-Falco and Salfeld, 1957; Arst, Manning, and Delp, 1959; Goldbarg, Pineda, and Rutenburg, 1959; Kowlessar, Haeffner, and Sleisenger, 1960). The clinical significance of raised levels of activity is still a matter of dispute, however, and systematic, comparative investigations of the correlation of leucine aminopeptidase activity with alkaline phosphatase activity and glutamic oxalacetic transaminase activity are not available.

The object of the present work is to contribute towards the elucidation of the clinical significance of raised serum leucine aminopeptidase activity and to compare its diagnostic value with that of the alkaline phosphatase and the glutamic oxalacetic transaminase activity in serum. For this purpose simultaneous determinations of the serum activities of the three enzymes mentioned have been made in a number of patients.

Leucine aminopeptidase is an exopeptidase belonging to the aminopeptidases (Smith, 1951). Its specificity is low (Smith and Spackman, 1955; Hill and Smith, 1957), and it has been demonstrated in most mammalian tissues (Goldbarg and Rutenburg, 1958; Rutenburg et al., 1958; Willighagen and Planteydt, 1959; Burstone and Folk, 1956; Adams, McFadden, and Smith, 1952; Pearse and Tremblay, 1958).

\footnotetext{
${ }^{1}$ Aided by a grant from the Danish Cancer Society.
}

\section{RESULTS OF PREVIOUS CLINICAL INVESTIGATIONS}

In an investigation of the peptidase content of human serum Fleisher and Butt (1953) found raised leucine aminopeptidase activity in hepatobiliary diseases. In a large group of patients, Fleisher et al. (1957) found the greatest increase in activity in acute epidemic hepatitis and less in neoplastic liver disease, bile duct obstruction, and portal cirrhosis. Goldbarg and Rutenburg (1958) and Rutenburg et al. (1958) found the highest leucine aminopeptidase activity in serum from patients with carcinoma of the head of the pancreas and significantly lower activity in choledocholithiasis and liver metastases. Arst et al. (1959) found, as did others (Braun-Falco and Salfeld, 1957), the highest activity in pregnant women during the last trimester. These authors also found considerably increased serum activities in hepatobiliary diseases, but they are not of the opinion that the analysis provides any differential diagnostic information within this disease group. Braun-Falco and Salfeld (1957) found increased leucine aminopeptidase activity in pemphigus vulgaris and in acute eczematous diseases.

\section{METHODS}

The leucine aminopeptidase activity in serum and bile was measured according to the method devised by Goldbarg and Rutenburg (1958).

The alkaline phosphatase activity in serum was determined according to the method devised by Kind and King (1954) and is stated in King-Armstrong units per $100 \mathrm{ml}$. serum.

The glutamic oxalacetic transaminase activity in serum was determined according to the method devised by 
Henley and Pollard (1955) and is stated in units per ml. serum.

Where the problem of significance is mentioned below, $p=0.05$ is taken to be the limiting value.

\section{CLINICAL MATERIAL}

Normal values for leucine aminopeptidase activity as well as for glutamic oxalacetic transaminase and alkaline phosphatase activity in serum were determined on the basis of analytical results from a group of patients selected in such a manner that those with clinical, biochemical, or signs at necropsy of hepatobiliary disease or congestive heart failure were excluded.

CHOLEDOCHOLITHIASIS This group comprises 16 patients with 17 admissions to the department. In 10 cases the diagnosis was confirmed by operation and in the remaining cases it is based on clinical and radiological examinations.

CHOLECYSTOLITHIASIS This group comprises 14 patients in whom the diagnosis was confirmed by operation or $x$-ray examination. Six out of the 14 were described as complicated by cholecystitis or cholangitis.

CARCINOMA OF THE PANCREAS This occurred in 11 cases in all. In eight patients the disease was found in the head of the pancreas, and four of them had metastases in the liver. In another three patients, the disease was found in the body of the pancreas accompanied by liver metastases in one, and in two in the tail of the pancreas, one of these with liver metastases.

LIVER METASTASES These were observed in 12 patients, the diagnosis being in all cases confirmed at necropsy. Patients with the pancreas as the site of the primary tumour are not included in this group.

CHRONIC HEPATITIS This group comprises 20 patients with 22 admissions to the department. In 12 cases the diagnosis was confirmed by liver biopsy, while in the remaining eight it was based solely on clinical and biochemical findings.

ACUTE HEPATITIS This is a group of six patients with typical clinical findings.

MYOCARDIAL INFARCTION This group comprises 37 patients with typical clinical findings and pathognomonic alterations in the electrocardiographic readings in the course of the disease. Seventeen of these patients died, necropsy was performed in 16 , and the diagnosis was confirmed in all. The mean values of the three enzymatic activities within this group were calculated on the basis of all the analyses in which a raised glutamic oxalacetic transaminase activity was observed, as well as on the basis of the analyses corresponding to maximum transaminase activity in the patients in whom all transaminase analyses gave results within the normal range. In nine of the 37 patients an enlarged liver due to congestive heart failure was observed, in six cases at necropsy and in three by palpation. These patients are classified separately.
RESULTS

glutamic OXALACETIC TRANSAminase The highest activity was found in patients with acute hepatitis (epidemic). In intra- and extrahepatic biliary obstruc- in tion and in myocardial infarction a moderate increase in the glutamic oxalacetic transaminase activity was observed. In patients with liver metastases normal activity was found in five out of 12 cases, but, when 10 cases of carcinoma of the pancreas with liver metastases are included, the frequency of normal activity was only five out of 22 cases.

ALKALINE PHOSPHATASE In this study the highest alkaline phosphatase activity was observed in cases of choledocholithiasis, carcinoma of the head of the pancreas (extrahepatic biliary obstruction), and in patients with liver metastases (intrahepatic biliary obstruction). There is no significant difference between the mean values obtained in these clinical groups.

Moderately raised alkaline phosphatase activity was found in serum from patients with acute (epidemic) hepatitis, chronic hepatitis, and cholecystolithiasis complicated by cholecystitis and cholangitis. The mean values for these diseases do not show any significant difference, but they are all significantly lower than the mean values prevailing in the case of intra- and extrahepatic biliary obstruction.

In myocardial infarction and in uncomplicated cholecystolithiasis the serum alkaline phosphatase activity was found to be normal.

Comparisons between the analytical results obtained for the alkaline phosphatase activity, glutamic oxalacetic transaminase activity, and bilirubin concentration in serum from patients with extra- or intrahepatic biliary obstruction (40 patients) show that all of the 62 alkaline phosphatase analyses gave pathological values, that 15 out of 71 glutamic oxalacetic transaminase analyses gave normal results ( $\leqq 2.0$ units $/ \mathrm{ml}$.), and that 11 out of 44 bilirubin concentrations were $\leqq 1.0 \mathrm{mg} . \%$ (Table I).

\section{TABLE I}

DISSOCIATION BETWEEN ANALYTICAL VALUES ON SERUM FROM 40 PATIENTS WITH INTRA- OR EXTRAHEPATIC BILIARY OBSTRUCTION

\begin{tabular}{lccc} 
& $\begin{array}{l}\text { Full } \\
\text { Analysis }\end{array}$ & Normal & Pathological \\
\hline Alkaline phosphatase & 62 & 0 & 62 \\
Leucine aminopeptidase & 71 & 0 & 71 \\
Go-T. & 71 & 15 & 56 \\
Serum bilirubin & 44 & 11 & 33
\end{tabular}


The 62 alkaline phosphatase analyses from patients with biliary obstruction and the 36 analyses from patients with parenchymatous liver diseases (acute and chronic hepatitis) are distributed about the value of $30 \mathrm{~K}$.-A. units $/ 100 \mathrm{ml}$. serum in such a manner that $16 \%$ of the values obtained in cases of obstructive disease are below this value and $14 \%$ of the values obtained in cases of parenchymatous disease are above this value.

LEUCINE AMINOPEPTIDASE The analytical results obtained for leucine aminopeptidase activity in serum are represented in Table II. The highest

\section{TABLE II}

ANALYTICAL RESULTS FOR THE LEUCINE AMINOPEPTIDASE ACTIVITY

\begin{tabular}{|c|c|c|c|c|}
\hline Diagnosis & $\begin{array}{l}\text { Mean } \\
\text { Activity } \\
\text { ( } \text { mol./h./n }\end{array}$ & $\begin{array}{l}\text { Standard } \\
\text { Deviation } \\
\text { ml.) }\end{array}$ & $\begin{array}{l}\text { Range } \\
\text { (max.-min.) }\end{array}$ & $\begin{array}{l}\text { No. of } \\
\text { Cases, } \\
\text { Tests }\end{array}$ \\
\hline \multirow{9}{*}{$\begin{array}{l}\text { Normal } \\
\text { Common duct } \\
\text { stone (total) } \\
\text { Common duct } \\
\text { stone (max.) } \\
\text { Cancer in } \\
\text { head of pancreas } \\
\text { Hepatic metastases } \\
\text { Chronic hepatitis } \\
\text { Epidemic hepatitis } \\
\text { Uncomplicated } \\
\text { cholecystolithiasis } \\
\text { Complicated } \\
\text { cholecystolithiasis } \\
\text { Coronary occlusion, } \\
\text { congested liver }\end{array}$} & 2.05 & 0.60 & $3 \cdot 30-0 \cdot 95$ & 85,102 \\
\hline & $7 \cdot 20$ & $2 \cdot 25$ & $12 \cdot 15-4 \cdot 50$ & 17,31 \\
\hline & $8 \cdot 25$ & $2 \cdot 40$ & $12 \cdot 15-5 \cdot 10$ & 17,17 \\
\hline & $\begin{array}{l}7 \cdot 20 \\
6.85\end{array}$ & $\begin{array}{l}2.25 \\
1.75\end{array}$ & $\begin{array}{l}12 \cdot 75-3 \cdot 85 \\
10 \cdot 20-4 \cdot 00\end{array}$ & $\begin{array}{r}8,15 \\
12,18\end{array}$ \\
\hline & $4 \cdot 50$ & 1.90 & $8 \cdot 35-0 \cdot 75$ & 22,22 \\
\hline & $4 \cdot 35$ & 1.80 & $8 \cdot 10-1 \cdot 65$ & 6,15 \\
\hline & 1.80 & 0.75 & $3 \cdot 30-0 \cdot 50$ & 8,10 \\
\hline & $5 \cdot 10$ & $2 \cdot 25$ & $10 \cdot 75-3 \cdot 00$ & 6,14 \\
\hline & 5.55 & 1.75 & $9 \cdot 80-3 \cdot 75$ & 9,13 \\
\hline Coronary occlusion & 2.05 & 0.60 & $3 \cdot 15-0.75$ & 28,58 \\
\hline
\end{tabular}

activities were encountered in patients with extraand intrahepatic biliary obstruction, and there is no significant difference between the mean values obtained in cases of choledocholithiasis, carcinomata of the head of the pancreas, and liver metastases.

Moderately raised leucine aminopeptidase activity is observed in patients with acute (epidemic) hepatitis, chronic hepatitis, cholecystolithiasis complicated by cholecystitis and cholangitis, and in patients with myocardial infarction complicated by hepatic congestion. The mean values obtained in these diseases do not differ significantly; they are all significantly lower than the values obtained in patients with biliary obstruction.

The mean values obtained from the normal group, from patients with myocardial infarction without congested liver, and from patients with uncomplicated cholecystolithiasis did not display significant differences, but they are all significantly lower than the remaining mean values given.
In the normal group no distinction has been made with regard to sex, and the average age is high. It is therefore important that the mean value obtained from this group $(2.05 \mu \mathrm{mole} / \mathrm{h} . / \mathrm{ml} ., \mathrm{SD}=0.60 \mu$ mole) does not differ significantly from the value $\mathrm{M}=2.40 \mu \mathrm{mole} / \mathrm{h} . / \mathrm{ml}$. (SD $=0.45 \mu \mathrm{mole})$, obtained from 34 physically healthy men between 18 and 24 years of age.

In the 40 patients with intra- or extrahepatic biliary obstruction, in whom a certain discrepancy was observed between the raised alkaline phosphatase activity on the one hand and the normal glutamic oxalacetic transaminase activity and normal serum bilirubin concentration on the other, we find that the 71 analyses of leucine aminopeptidase activity all demonstrate pathological activity.

An attempt to find a value for serum leucine aminopeptidase activity which represents the borderline between values obtaining in parenchymatous liver diseases and those corresponding to choledocholithiasis, carcinoma of the head of the pancreas, and liver metastases gave the result that the value $5.40 \mu \mathrm{mole} / \mathrm{h} . / \mathrm{ml}$. divides the results in such a manner that $25 \%$ of 37 analyses from parenchymatous diseases lie above this value and $20 \%$ of 71 analyses from obstructive diseases lie below it.

A few patients with pathological serum leucine aminopeptidase values could not be included in any of the disease groups mentioned, viz., patients suffering from malignant tumours in whom the presence of liver metastases had not been ascertained, patients with hepatic congestion resulting from a severe congestive heart failure, and patients with various hepatobiliary diseases (Table III).

\section{TABLE III}

LEUCINE AMINOPEPTIDASE, ALKALINE PHOSPHATASE, AND GLUTAMIC OXALACETIC TRANSAMINASE ACTIVITY IN SERUM IN HEPATO-BILIARY DISEASE

\begin{tabular}{|c|c|c|c|}
\hline Diagnosis & $\begin{array}{l}\text { Leucine } \\
\text { Amino- } \\
\text { peptidase }\end{array}$ & $\begin{array}{l}\text { Alkaline } \\
\text { Phosphatase }\end{array}$ & $\begin{array}{l}\text { Glutamic } \\
\text { Oxalacetic } \\
\text { Transaminase }\end{array}$ \\
\hline Chronic pancreatitis & $6 \cdot 30$ & $34 \cdot 8$ & 0.3 \\
\hline Chronic pancreatitis & $5 \cdot 10$ & $53 \cdot 3$ & \\
\hline Chlorpromazine jaundice & 10.95 & $27 \cdot 7$ & $5 \cdot 0$ \\
\hline Infectious mononucleosis & $11 \cdot 70$ & $47 \cdot 6$ & 16.9 \\
\hline $\begin{array}{l}\text { Metastases to lymph nodes } \\
\text { of porta hepatis }\end{array}$ & $6 \cdot 15$ & $36 \cdot 0$ & $3 \cdot 5$ \\
\hline
\end{tabular}

In post-operative bile obtained by $T$-tube from patients operated upon for cholelithiasis or diseases of the pancreas we have found leucine aminopeptidase activities up to four times as high as the highest serum activities measured. We also found that the leucine aminopeptidase activity in serum is independent of the function of the kidneys measured by the serum creatinine concentration. 
Our results for glutamic oxalacetic transaminase activity in serum agree closely with the large number of available results reviewed by Wróblewski (1959). It appears from Table IV, as is stated elsewhere (Wróblewski and LaDue, 1955), that glutamic oxalacetic transaminase activity in serum is independent of the alkaline phosphatase activity. We are also unable to ascertain any correlation with serum leucine amonopeptidase activity. On the other hand, a comparison between leucine aminopeptidase and alkaline phosphatase activity in serum (Table IV and Fig. 1) shows considerable correlation. As in the case of alkaline phosphatase (Gutman, 1959; Gutman, Olson, Gutman, and Flood, 1940; Van der Meer, 1946), the highest serum leucine aminopeptidase activity is observed in biliary obstruction and lower activity in acute and chronic hepatitis and cholecystolithiasis complicated by cholecystitis and cholangitis. Our analytical results with regard to alkaline phosphatase activity in obstructive and parenchymatous liver diseases are distributed in the usual manner about the value $30 \mathrm{~K}$.-A. units $/ 100 \mathrm{ml}$.

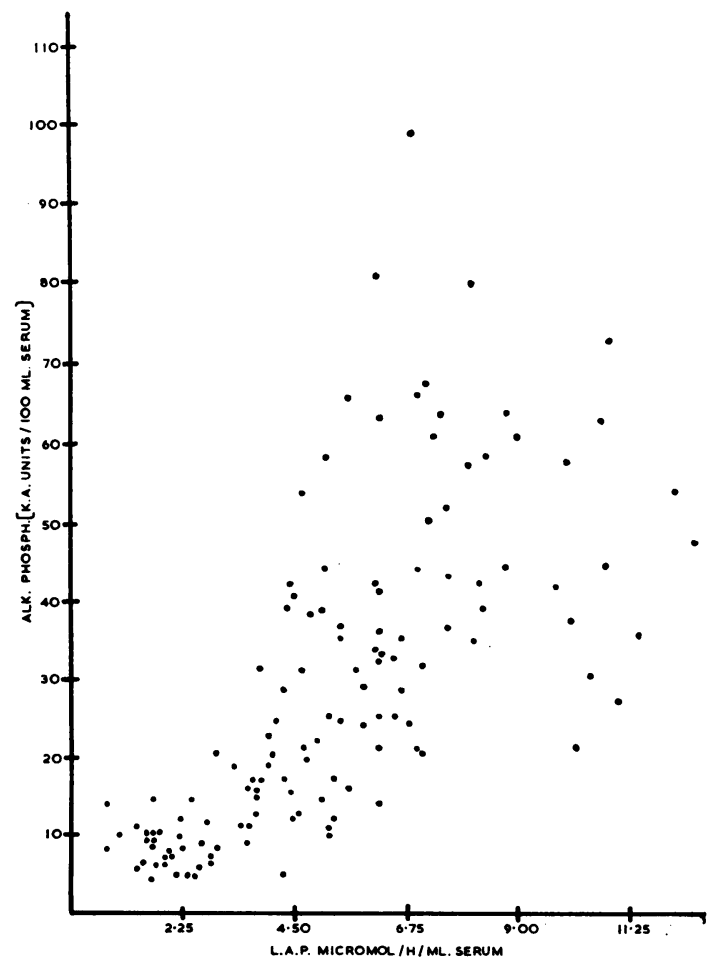

FIG. 1. Relation between corresponding values of leucine aminopeptidase and alkaline phosphatase activity in serum from all patients suffering from hepato-biliary conditions.
MEANS OF ENZYMATIC ACTIVITY IN CLINICAL GROUPS OF PRESENT SERIES

\begin{tabular}{|c|c|c|c|}
\hline Diagnosis & $\begin{array}{l}\text { Leucine } \\
\text { Amino- } \\
\text { peptidase } \\
(\text { ( mol. } / \mathrm{h} . / \mathrm{ml} .)\end{array}$ & $\begin{array}{l}\text { Alkaline } \\
\text { Phosphatase } \\
\text { (K.-A. units) } \\
\text { ) }\end{array}$ & $\begin{array}{l}\text { GO-T. } \\
\text { (units/ml.) }\end{array}$ \\
\hline Normal & $2 \cdot 05$ & $8 \cdot 0$ & $1 \cdot 1$ \\
\hline Common duct stone (total) & $7 \cdot 20$ & $43 \cdot 3$ & $4 \cdot 8$ \\
\hline $\begin{array}{l}\text { Common duct stone (max.) } \\
\text { Cancer in the }\end{array}$ & $8 \cdot 25$ & $42 \cdot 1$ & $5 \cdot 0$ \\
\hline head of pancreas & $7 \cdot 20$ & $56 \cdot 5$ & 4.9 \\
\hline Hepatic metastases & 6.85 & $44 \cdot 3$ & $6 \cdot 4$ \\
\hline Chronic hepatitis & $4 \cdot 50$ & $21 \cdot 4$ & $8 \cdot 9$ \\
\hline Epidemic hepatitis & $4 \cdot 35$ & $21 \cdot 0$ & 16.9 \\
\hline Uncomplicated & & & \\
\hline $\begin{array}{l}\text { cholecystolithiasis } \\
\text { Complicated }\end{array}$ & $1 \cdot 80$ & $9 \cdot 0$ & $1 \cdot 4$ \\
\hline cholecystolithiasis & $5 \cdot 10$ & $23 \cdot 8$ & $4 \cdot 6$ \\
\hline $\begin{array}{l}\text { Coronary occlusion, } \\
\text { congested liver } \\
\text { Coronary occlusion }\end{array}$ & $\begin{array}{l}5 \cdot 55 \\
2 \cdot 05\end{array}$ & $8 \cdot 8$ & $\begin{array}{l}5 \cdot 4 \\
7 \cdot 0\end{array}$ \\
\hline
\end{tabular}

(Gutman, 1959; Gutman et al., 1940), and it seems as if a similar borderline value may be found for serum leucine aminopeptidase activity in these two disease groups, namely, $5 \cdot 40 \mu \mathrm{mole} / \mathrm{h} . / \mathrm{ml}$.

In patients with extra- and intrahepatic biliary obstruction a dissociation between raised alkaline phosphatase activity and normal serum bilirubin concentration (Gutman et al., 1940; Simons, 1954; Gibbons, 1957; Brem, 1955) has been described. In the present investigation this phenomenon applies uniformly to alkaline phosphatase as well as to leucine aminopeptidase activity. We find a similar dissociation between pathological activities of these two enzymes and normal glutamic oxalacetic transaminase activity (Table I).

Our results do not support the view held by Goldbarg and Rutenburg (1958) and Rutenburg et al. (1958) that the highest serum leucine aminopeptidase activity should indicate carcinoma of the pancreas. Unlike Arst et al. (1959), however, we are of the opinion that the determination of the leucine aminopeptidase activity in serum from jaundiced patients may be used to distinguish between parenchymatous and obstructive liver disease with the same reservations and the same uncertainty as those applying to alkaline phosphatase activity. In addition, raised leucine aminopeptidase activity may, as does a raised level of alkaline phosphatase activity (Gibbons, 1957), call attention to the possibility that a state of anicteric biliary obstruction exists. This view is supported by a recent work by Witts and Perry (1960). Likewise, Shay, Sun, and Siplet (1960) have recently concluded that raised serum leucine aminopeptidase activity must, as does raised alkaline phosphatase activity, be an indication of biliary obstruction. 
Schwartz and Myers (1954) have shown that bilateral nephrectomy does not influence the peptidase activity of serum, but that the latter is reduced by its passage through the liver to such an extent that the arteriovenous deficit across the liver is proportional to the serum activity. They assume that these observations support the theory that serum peptidase is eliminated by the liver. Our observations (maximum serum activities in biliary obstruction, high enzymatic activity in bile) support the view of Schwartz and Myers, and suggest that the enzyme is eliminated by excretion in the bile.

\section{CONCLUSION AND SUMMARY}

In this comparative investigation of the clinical significance and diagnostic value of leucine aminopeptidase activity in serum, a pathologically raised level of activity has been observed in serum from patients with primary or secondary hepatobiliary diseases only. In these conditions the leucine aminoheptidase activity is closely related to that of the alkaline phosphatase in serum, with the same degree of elevation and the same relationship to the glutamic oxalacetic transaminase activity and bilirubin concentration in serum. The leucine aminopeptidase and alkaline phosphatase activities in serum are equivalent indicators of biliary obstruction but neither are of any value in differing between the causes of obstruction and both equally serve in differentiating obstructive from parenchymatous jaundice. Therefore, in the case of pancreatic cancer, a raised level of leucine aminopeptidase activity in serum must be considered due either to compression of the common bile duct by the primary tumour, to intrahepatic biliary obstruction caused by metastases to the liver, or to both.

\section{REFERENCES}

Adams, E., McFadden, M., and Smith, E. L. (1952). Peptidases of erythrocytes. I. Distribution in man and other species. J. biol. Chem., 198, 663-670.

Arst, H. E., Manning, R. T., and Delp, M. (1959). Serum leucine aminopeptidase activity: Findings in carcinoma of the pancreas, pregnancy and other diseases. Amer. J. med. Sci., 238, 598-609.

Braun-Falco, O., and Salfeld, K. (1957). Uber das Verhalten der Leucin-Aminopeptidase-Activităt im Blutserum und Blaseninhalt. Arch. klin. exp. Derm., 205, 103-111.

Brem, T. H. (1955). Recognition of biliary tract obstruction without jaundice. J. Amer. med. Ass., 159, 1624-1626.

Burstone, M. S., and Folk, J. E. (1956). Histochemical demonstration of aminopeptidase. J. Histochem. Cytochem., 4, 217-226.
Fleisher, G. A., and Butt, H. R. (1953). Peptidases in human serum: A comparison of activities between normal persons and patients with liver diseases and other pathological conditions. J. clin. Invest., 32, 674-680.

- , - and Huizenga, K. A. (1957). Enzymatic hydrolysis of 1-leucylglycine in serum in hepatic disease. Proc. Mayo Clin., 32, 410-424.

Gibbons, T. B. (1957). Hyperphosphatasemia in patients without jaundice with hepatobiliary disease. J. Amer. med. Ass., 164, 22-28.

Goldbarg, J. A., and Rutenburg, A. M. (1958). The colorimetric determination of leucine aminopeptidase in urine and serum of normal subjects and patients with cancer and other diseases. Cancer (Philad.), 11, 283-291.

_- Pineda, E. P., and Rutenburg, A. M. (1959). The measurement of activity of leucine aminopeptidase in serum, urine, bile, and tissues. Amer. J. clin. Path., 32, 571-575.

Green, M. N., Kwan-Chung Tsou, Bressler, R., and Seligman, A. M. (1955). The colorimetric determination of leucine aminopeptidase activity with L-leucyl- $\beta$-naphthylamide hydrochloride. Arch. Biochem., 57, 458-474.

Gutman, A. B. (1959). Serum alkaline phosphatase activity in diseases of the skeletal and hepatobiliary systems. Amer. J. Med., 27, 875-901.

- Olson, K. B., Gutman, E. B., and Flood, C. A. (1940). Effect of disease of the liver and biliary tract upon the phosphatase activity of the serum. J. clin. Invest., 19, 129-152.

Henley, K. S., and Pollard, H. M. (1955). A new method for the determination of glutamic oxalacetic and glutamic pyruvic transaminase in plasma. J. Lab. clin. Med., 46, 785-789.

Hill, R. L., and Smith, E. L. (1957). Leucine aminopeptidase. VII Action on long chain polypeptides and proteins. J. biol. Chem., 228, 577-600.

Kind, P. R. N., and King, E. J. (1954). Estimation of plasma phosphatase by determination of hydrolysed phenol with aminoantipyrine. J. clin. Path., 7, 322-326.

Kowlessar, O. D., Haeffner, L. J., and Sleisenger, M. H. (1960). Localization of leucine aminopeptidase in serum and body fluids by starch gel electrophoresis. J. clin. Invest., 39, 671-675.

Pearse, A. G. E., and Tremblay, G. (1958). Leucine aminopeptidase in rat parathyroid and its relation to parathyroid hormone production. Nature (Lond.), 181, 1532-1533.

Rutenburg, A. M., Goldbarg, J. A., and Pineda, E. P. (1958). Leucine aminopeptidase activity. Observations in patients with cancer of the pancreas and other diseases. New Engl. J. Med., 259, 469-472.

Shay, H., Sun, D. C. H., and Siplet, H. (1960). Leucine aminopeptidase: Significance of serum elevations in disease of the hepatobiliary-pancreatic system. Amer. J. dig. Dis., 5, 217-232.

Schwartz, T. B., and Myers, J. D. (1954). Observations on the visceral removal of plasma peptidase activity. J. clin. Invest., 33, 337-341.

Simons, R. L. (1954). Hepatic tests in metastatic carcinoma of the liver. A review of seventy-three cases proven at necropsy. Amer. J. med. Sci., 228, 312-316.

Smith, E. L. (1951). The specificity of certain peptidases. II. Leucine aminopeptidase. Advanc. Enzymol., 12, 196-206.

- and Spackman, D. H. (1955). Leucine aminopeptidase. V. Activation, specificity, and mechanism of action. J. biol. Chem. 212, 271-299.

Van der Meer, P. (1946). The phosphatase content of the serum in jaundice. Acta med. scand., 126, 265-272.

Willighagen, R. G. J., and Planteydt, H. T. (1959). Aminopeptidase activity in cancer cells. Nature (Lond.), 183, 263-264.

Witts, L. J., and Perry, S. W. (1960). Leucine aminopeptidase with special reference to ulcerative colitis. Gut, 1, 140-141.

Wróblewski, F. (1959). The clinical significance of transaminase activities of serum. Amer. J. Med., 27, 911-923.

- and LaDue, J. S. (1955). Serum glutamic-oxalacetic-transaminase activity as an index of liver-cell injury from cancer. Cancer (Philad.), 8, 1155-1163. 